\title{
Governing Knowledge: Intellectual Property Management for Development and the Public Interest
}

\author{
Leonardo Burlamaqui \\ University of the State of Rio de Janeiro \\ The Levy Economics Institute- NY
}

\begin{abstract}
The core point of this paper is the hypothesis that in the field of intellectual property rights and regulations, the last three decades witnessed a big change. The boundaries of private (or corporate) interests have been hyper-expanded while the public domain has significantly contracted. It tries to show that this is detrimental to innovation diffusion and productivity growth. The paper develops the argument theoretically, fleshes it out with some empirical evidence and provides a few policy recommendations on how to redesign the frontiers between public and private spaces in order to produce a more democratic and development-oriented institutional landscape. The proposed analytical perspective developed here, "Knowledge Governance", aims to provide a framework within which, in the field of knowledge creation and diffusion, the dividing line between private interests and the public domain ought to be redrawn. The paper's key goal is to provide reasoning for a set of rules, regulatory redesign and institutional coordination that would favor the commitment to distribute (disseminate) over the right to exclude.
\end{abstract}

Keywords: knowledge management, intellectual property, patent, public interest, public sector, private sector, socioeconomic developmen 


\section{Introduction $^{1}$}

"The field of knowledge is the common property of mankind." Thomas Jefferson

The core point of this paper is the hypothesis that in the field of intellectual property rights and regulations, the last three decades witnessed a big change. The boundaries of private (or corporate) interests have been hyper-expanded while the public domain has significantly contracted. The paper tries to show that this is detrimental to innovation diffusion and productivity growth. (cf. BROWN-KEYDER 2007; BOYLE 2008; RODRIK 2011 and BURLAMAQUI and CIMOLI 2014 for similar lines of reasoning).The paper develops the argument analytically, fleshes it out with some empirical evidence and provides a few policy recommendations on how to redesign the frontiers between public and private spaces. The result would be a more open, democratic and development-oriented institutional landscape in the fields of knowledge creation and appropriation. This "Knowledge Governance", analytical perspective developed here proposes a framework within which, in the field of knowledge creation, diffusion and appropriation, the dividing line between private interests and the public domain ought to be redrawn. The paper's key goal is to provide reasoning for a set of rules, regulatory redesign and institutional coordination that would favor the commitment to distribute (disseminate) over the right to exclude.

In 2005, Mark Blaug made a prescient, remark in that matter:

"It never occurred to anyone before, say the 1980s, that such disparate phenomena as patents for mechanical inventions, industrial products and processes (now extended to biotechnology, algorithms and even business methods), copyrights for the expression of literacy and artistic expressions in fixed form and trademarks and trade names for distinctive services, could be generalized under the heading of property rights, all conferred by the legal system in relation to discrete items of information resulting from some sort of appropriate intellectual activity". (BLAUG 2005, 71-72, italics added)

For the purposes of the arguments in this paper, there are two crucial elements implicit in Blaug's statement. First, that, as recently as in the seventies, the balance between private interests and the public domain was completely different from what it has become today. Second, that what became codified, and largely

\footnotetext{
${ }^{1}$ This paper is an outgrowth of recent papers published by the author (BURLAMAQUI: 2009b, 2014 and BURLAMAQUI and CIMOLI: 2014).
} 
accepted, as intellectual property rights was, until then, understood as a set of rules and regulations issued by the state, granting temporary monopolies to corporations in very specific cases. Recent history seems to back both Blaug's statement and my hypothesis. Until the 1970s, United States patents were seen as monopolies (a term with distinctly negative connotations at that time), not rights. In fact, in some areas of economic activity, it would have been possible to say that upholding the validity of IP was the exception rather than the rule (BROWN-KEYDER 2007, 159). This was reflected in IP law as well as in competition or antitrust law. In copyrights, the term under United States law was 28 years.

The early 1970s witnessed several dramatic changes. In 1974, a trade act allowed the Federal Trade Commission to bring sanctions directly against countries whose products were seen to hurt United States interests. In 1975, copyrights were expanded to over 70 years from the death of the author, and for corporate owners, to 95 and sometimes even 120 years (BROWN-KEYDER 2007, 158; BOYLE 2008 , ch. 1). In 1979, Section 301 of the United States trade law was amended to "allow private parties to take significant and public steps to enforce international trade agreements" (BROWN-KEYDER 2007, 160). In 1988, the Justice Department rescinded guidelines for antitrust prohibitions on certain kinds of licensing clauses. This removed IP licensing from antitrust scrutiny. Finally, with the enactment of the WTO in 1995, the TRIPs agreement quickly became the linchpin of United States trade strategy. By then, private corporations had vastly expanded their enforcement power and global outreach, while the public domain had significantly contracted.

From a knowledge governance perspective, the critical question is this: When does extended protection cease to work for generating Schumpeterian profits and become a base for rent-seeking and rent extraction. ${ }^{2}$ There is no good theoretical answer to this, but recent data on declining R\&D expenditures correlating with the maintenance of handsome profits in big pharma seems to emphasize its relevance (cf. "Supply Running Low." Financial Times 10 February 2011).As an alternative to the "strong IPRs" mainstream approach, new insights and evidence are beginning to appear. Besides the already cited studies, a few papers and books are laying the ground for a very different way to understand the complex interactions among knowledge production, appropriation and diffusion. Examples include Jerome Reichmann's work, the comparative and interdisciplinary research led by Richard Nelson, Akira Goto and Hiro Odagiri on intellectual property and catching-up and the collection of essays edited by Fred Block and Mathew Keller on the role of the US government in technology development ( REICHMANN et alii: 2014,ODAGIRI et alii:2010, BLOCK and KELLER eds: 2011).

\footnotetext{
${ }^{2}$ See Arnold Plant's point below on that matter.
} 
However, notwithstanding the valuable contributions by this emerging body of research, the main analytical question remains largely untouched: How should government-issued intellectual property rules and regulations interact with publicly funded $R \& D$ research and competition policies ${ }^{3}$, in order to help craft and govern socially inclusive development strategies? It appears there is no coherent analytical framework to address that interaction. ${ }^{4}$ However, those links are central to any meaningful discussion of dynamic competition, knowledge accumulation and diffusion, and sustainable development in a global context today. ${ }^{5}$

This paper aims to contribute to answering that question. Section II lays the ground rules by linking knowledge production and dynamic competition with intellectual property issues from the perspective of the dynamic efficiencies and inefficiencies that are bound to appear. It will become clear that the existence of dynamic inefficiencies opens up a considerable space for public interest based "knowledge governance" policies and regulations. Section III further develops the previous framework by linking competition and technology policies with intellectual property. Special attention is given to how competition policies should link publicly funded R\&D to intellectual property rules issues under a Knowledge governance approach.. Section IV concludes the paper by suggesting some broader theoretical and policy implications of that approach.

\section{Knowledge production, dynamic inefficiencies and the role of knowledge governance}

In the context of Schumpeterian competition, intellectual property rules and regulations (IPRs) - patents, trade secrets, confidentiality contracts, copyrights, trademarks and registered brand names - became powerful, strategic weapons for generating sustained competitive advantages and, especially, Ricardian rents (cf. SCHUMPETER: 1934, PLANT 1934). ${ }^{6}$

\footnotetext{
${ }^{3}$ A much less catchy label but one that reveals their real nature much better than "rights."

${ }^{4}$ This does not imply a shortage of work discussing specific issues in what is called "the economics of intellectual property rights." See Menell (1999) for an excellent survey on general theories of IP. A very interesting review acknowledging the under-researched nature of the theme can be found in Dixon and Greenlalgh (2002). The shortcomings of most of that work are, from my perspective, the result of its concentration on "data," "measures" and "testing," with little attention paid to the theoretical framework within which they are conducted.

${ }^{5}$ From an evolutionary perspective, evolution should not be confused with progress (a very common mistake), but as a process, it should definitively be understood as entailing increasing complexity.

${ }^{6}$ Having said that, it is striking how little has been written about the crucial and complex connection between Schumpeterian competition and IPRs. We include ourselves in that loophole. In that regard, legal theorists such as Landes and Posner and Benkler are clearly ahead, in the sense that they are already doing the reverse - using Schumpeterian concepts and insights to deal with IPRs (cf. LANDES and POSNER 2003, BENKLER 2006).
} 
From an entrepreneurial perspective, patents and other IPRs are extremely effective means to reduce uncertainties and therefore can contribute to igniting the animal spirits and long-term expectations through building temporary monopolies around products, processes, market niches and, eventually, whole markets (NELSON 1996; BurlamaQUI and PROENÇA 2003). However, the word temporary is crucial here because of creative destruction; as Schumpeter $(1994,102)$ stated long ago, "A monopoly position is in general no cushion to sleep on."7

The Chicago Law and Economics framework claims that in the absence of robust legal protection for an invention, the inventor either will have less incentive to innovate or will try to keep his invention secret, thus reducing, in both cases, the stock of knowledge to society as a whole (LANDES and POSNER 2003, 294). From that perspective, patent law itself supposedly internalizes the goal of promoting the diffusion of innovation. ${ }^{8}$ It requires, as a condition of granting a patent, that the patent application disclose the steps constituting the invention in sufficient detail to enable readers of the application, if knowledgeable about the relevant technology, to manufacture the patented product themselves. Of course, anyone who wishes to replicate a patented product or process legally will have to negotiate a license with the patentee (Jolly and PHILPOTT 2004, pt. 1; LANDES and POSNER 2003, 294-295).

Moreover, any reader of the patent application will be free to "invent around" it, to achieve the technological benefits of the patent by other means without infringing on the patent. Translated to evolutionary economics jargon, the requirement of public disclosure creates a situation of "incomplete appropriability" for the patent holder. That links directly to Schumpeter's insight on the temporary nature of monopolies: incomplete appropriability allows for the possibility of technological inventiveness and borrowing from publicized information, both of which foster creative-destruction processes that are the main challengers of established monopolistic positions. Thus, if carefully used, intellectual property rules can be sources of dynamic efficiencies that can help to ignite the Schumpeterian positivesum game represented by falling costs, falling prices, positive margins (achieved through market power) and increased consumer welfare. ${ }^{9}$

Those are the basics, but the picture gets much more complicated as we examine the details. When we dive into the depths of the relationship between innovation and IP laws and regulations, considerable space opens up for dynamic inefficiencies to emerge and, therefore, for the introduction of governance considerations and

\footnotetext{
7 However, a strong IP regime is precisely the kind of "institutional innovation" that can help to build that cushion. Addressing this problem is one of the core issues of the knowledge-governance approach.

${ }^{8}$ Reference here is to American patent law.

${ }^{9}$ From here on, I will label this "Schumpeterian positive-sum game" as the "Schumpeterian package."
} 
for the emergence of a knowledge-governance approach. Consider the following six points.

First, as Sir Arnold Plant, an almost forgotten analyst in the field, observed in the early 1930s,

"In the case of physical property, the institution of private property makes for the preservation of scarce goods. ... In contrast, property rights in patents and copyrights make possible the creation of scarcity of the products appropriated. ... the beneficiary is made the owner of the entire supply of a product for which there may be no easily obtainable substitute." (PLANT 1934, 65-67, emphasis added)

In sum, intellectual property regulations can easily give rise to dynamic inefficiencies such as cumulative monopoly power to extract rents from a given consumer base, notwithstanding the fact that they can at the same time create the conditions for the expansion of productivity and wealth and the generation of Schumpeterian profits. ${ }^{10}$ That in itself leaves ground for knowledge-governanceoriented initiatives to enter the scene ${ }^{11}$, as we will see shortly.

Second, the broader - and stronger - the IPRs, generally, the less the patentee's competitors will be able to benefit from the patent by "inventing around," or innovating on the shoulders of, the patent (or copyright) holder. Broad IPRs are thus bound to exacerbate the dynamic inefficiencies that Plant and others have observed. Accordingly, especially given the complexity and diversity of patents and other IPRs, a one-size-fits-all prescription seems ill-advised. From an analytical point of view, the articulation between competition policies and IPRs is a much needed development ${ }^{12}$, especially if the former's goal is innovation diffusion and delivering the Schumpeterian package, not innovators' protection per se.

Third, the practice of strategic patenting, that is, the proliferating business strategy of applying for patents that the company has no intention of using, or exploiting, solely to prevent others from profiting from the innovation (cf. VARIAN, FARREL and SHAPIRO 2004, pt. 2; LANDES and POSNER 2003, ch. 11). Obviously, this is a major source of dynamic inefficiency. It has the effect of shifting resources from true innovative activity to litigation (or from labs to courts). It drastically increases the costs of patent prosecution and litigation and, therefore, of innovation.

\footnotetext{
${ }^{10} \mathrm{Or}$, in a more technical way of saying it, the expected (negative) impact on future incentives for competitors to compete (innovate) and future consumer welfare (see ANTHONY 2000, sect. IV.)

${ }^{11}$ On policy prescriptions, institutional building, institutional coordination and regulatory redesign.

${ }^{12}$ We will use the term "competition policies" rather than "antitrust" here because of the outdated connotation of the latter. We will not discuss "trust-busting", but a much more subtle and complex set of behaviors, institutions and policy tools.
} 
Such strategic patenting constitutes a paradigmatic example of what Baumol has called "unproductive entrepreneurship." Baumol notes:

"... [a] variety of roles among which the entrepreneur's efforts can be reallocated ... and some of those roles do not follow the constructive and innovative script conventionally attributed to that person. Indeed, at times the entrepreneur may even lead a parasitical existence that is actually damaging to the economy. (cf. BAUMol 1993, ch. 2, 25; see also ch. 4)".

Evidently, this task of "reallocation of entrepreneurship" (from unproductive roles to productive ones) is a knowledge-governance matter and one that goes far beyond the common notions associated with industrial and technology policies.

Fourth, IPRs have a central role in the "digitally renewed economy", as Paul David would label it, (Cf. DAVID in BRYNJOLFSSON and KAHIN 2002, 85). In so-called "neweconomy industries", intellectual property, rather than the products and processes in and of themselves, is a firm's primary output or asset. Overlapping innovations, rapidly falling average total costs, zero marginal costs, strong network externalities and, therefore, fierce "standards battles" and "lock-in" situations are the hallmarks of new-economy industries (SHAPIRO and VARIAN 1999; BEST 2001; DE LONG 2000; BRYNJOLFSSON and MCAFEE: 2011). These industry-structure characteristics might be seen as generating speeding waves of creative destruction and, thus, potentially more (not less) fiercely competitive challenges to incumbents. Although there is an element of truth in that picture, creative destruction in a world of increasing returns of scale, fast learning and "winner-takes-all" markets does not mean anything close to some idealized form of "perfect competition" or perfectly contestable markets. Rather, it merely brings the replacement of one, or a few, dominant firms by others, such as the replacement of Fairchild by Intel, of Ciba and Geigy by Pfizer and Novartis, of Wang and Compaq by Dell and Samsung, of IBM by Microsoft and Lenovo and of Microsoft by Google and Apple.

In other words, in the new economy, firms' abilities to combine first-mover advantages with trade secrets, patents, copyrights, brand loyalties and network externalities may afford them secure long-lasting monopolistic positions despite their low rate of (radical) innovations and not because of it. ${ }^{13}$ The outcome is,

\footnotetext{
${ }^{13}$ See Landes and Posner's (2003, 395-396) somewhat reluctant recognition of that point. The case of Microsoft itself can be used to illustrate the point. The lack of breakthroughs - technological innovations or radical quality/ price improvements - is notoriously known in Microsoft. It is well known that the "Windows" model was copied from Apple's user interface - which itself was a second-hand theft from Xerox PARC - as well as the tremendous lack of perception, by the company, of the Internet potential until the success of Netscape became obvious. It is also known that the differences between the versions of Windows and Office that I am using right now, although "new", display very pale improvements in relation to their 1998 predecessors.
} 
once more, the danger of replacing Schumpeterian profits with rent extraction and Schumpeterian competition with zero-sum game exclusionary practices. From the perspective of delivering the "Schumpeterian Package", there is an obvious role for knowledge governance here in restoring the balance between private interests and the public domain (cf. BoYLE 2008, Ch. 8-10). However, the normative policy framework within which it should take place is far from certain. I will revisit it in the next section.

Fifth, if we understand knowledge production as a cumulative, and increasingly globalized ${ }^{14}$, process in which cutting-edge knowledge and expertise rest on previous innovations, and if we conceive of patents and IPRs, in general, as fences erected to protect those previous innovations, we get a very different outcome. It is not difficult to perceive, depending on the institutional design within which IPRs are handled, the tension and potential trade-off between private interests and the conception of knowledge as a global public good. This is the so-called argument of the "secondenclosure movement" or "information feudalism," which is now the subject of intense debate (cf. DraHOS and BRAITHWAITE 2002, BOYLE 2003 and 2008, EVANS 2005, TeCHNOlogy ReVIEW 2005). According to Evans (discussing Boyle's ideas),

"There are really two halves to the second-enclosure movement. The defensive side focuses on intensifying the enforcement of protected monopoly rights to exclude others from using information that has been defined as private property. The offensive side of the agenda involves taking information that has been considered part of "nature", or the common, cultural and informational heritage of humankind, and transforming it into "private property". If both halves are successful, the "second-enclosure movement" would constitute a global re-distribution of property comparable to the eradication of the commons that ushered in agrarian capitalism in Western Europe 300 years ago". (Evans 2005, 2; emphasis added)

Once more, we encounter strong forces of global dynamic inefficiencies, presenting an opportunity for knowledge-governance-oriented policies to step in.

Sixth, to the question "where do knowledge and innovations come from in the developed nations?" a very large part of the answer would include: publicly funded $R \& D$, government contracting to buy things from the private sector that do not exist and using the WTO to help open up markets for those innovations abroad (BLOCK 2008, WEISS 2008, 2009). In the case of the United States, armed with an annual procurement budget of US\$450 billion - more than 1 trillion if states are included

\footnotetext{
${ }^{14}$ In the sense of its increasingly geographical dispersion, but not denoting any sign of broader inclusion or democratic orientation.
} 
- the state plays a crucial role in governing the way knowledge and innovations prosper in the United States (RUTTAN 2006; WEISS 2009). Furthermore, according to some recent studies, the United States government played a decisive part in the development of virtually all general-purpose technology, from interchangeable parts and mass production to DARPA and biotech (cf. RUTTAN 2006, WEISS 2007, BLOCK 2008, BLOCK and KELLER 2011). ${ }^{15}$

Let me rephrase this point: If we conceive R\&D as "turning money into knowledge" and innovation as "turning knowledge into money," why should governments (i.e., public money) heavily subsidize the former and almost completely retreat from participating in the latter?

Last, the institutional structure - or institutional design - within which the knowledge-production appropriation and diffusion apparatus is enforced is central for understanding its performance. We refer here not to the rules, as such, but to their legal enforcement apparatuses, the state structures by which they are supported and the sort of public bureaucracies available to administer the R\&D and IP systems. Jaffe and Lerner's (2002) thoughtful and provocative work on the recent changes in the United States patent system provides the background for our discussion, which will draw on the relationship between the institutional design of the United States patent system and the problems it creates for the promotion of innovation and "productive entrepreneurship" .

All six issues discussed above illustrate how the interaction between Schumpeterian competition and hyperextended intellectual property rules and regulations can give rise to dynamic inefficiencies that risk the delivery of the "Schumpeterian Package" and call for knowledge-governance interventions to restore the balance between private interests and the public good (or public interest.

\section{Knowledge governance: Bringing the public domain back in}

Knowledge governance (KG) is a broad concept embracing different forms of governance mechanisms influencing the production, dissemination and appropriability of knowledge. The "knowledge-governance approach" is an emerging approach that cuts across the fields of knowledge creation and management, innovation and competition policies and state capacities. KG deals with how the deployment of governance mechanisms influences knowledge processes, such as sharing, retaining and creating knowledge. As an analytical perspective, it encompasses intellectual property rules and regulations but supersedes it, drawing

\footnotetext{
${ }^{15}$ DARPA is the Defense Advanced Research Projects Agency, the central research organization of the United States Department of Defense. Its most radical innovation was the Internet (known first as ARPANET).
} 
on those aforementioned fields and disciplines in order to design the contours of a new knowledge ecology. KG's main goal is to design, support and implement public interest oriented governance mechanisms, as well as organizational and business models which are alternatives to the instituted intellectual property regime we now have (BURLAMAQUI 2009b). Within the knowledge governance approach, the general rule should be the promotion of innovation (not the innovator) and the assurance of its widest diffusion. This implies, simultaneously, promoting and regulating entrepreneurial success. Promoting and regulating is a crucial link here. Together, they address both the private (profit seeking) and the public (innovationdiffusion and technological-upgrading) sides of competition policies and their respective institutional designs.

This policy and institutional-design package was, in fact, the core of the Asian state-centered developmental strategy. Nowadays, it remains alive and well in East Asia. In Singapore, it is evident in the country's twin government-sponsored initiatives. On "biomedical sciences" and on "work restructuring," where marketshaping and institutional coordination are the core elements (PEREIRA 2008). In China, it is clearly present in the 12th five-year plan for 2011 to 2015, finalized last April. The plan highlights the importance of the "magic seven" industries: (1) energy saving and environmental protection, (2) next-generation information technology, (3) biotechnology, (4) high-end manufacturing, (5) new energy, (6) new materials and (7) clean-energy vehicles. The plan's objective is to "shape" them in order to raise their share from 3 percent to 15 percent of the economy by 2020 .

None of those countries labels their government-sponsored initiatives as knowledge governance, but it is quite clear that this is what they really are: going much beyond "industrial policy" or "intellectual property", they reach the key interactions between knowledge and markets ... and shape them from a publicpolicy/public-interest perspective.

From a normative perspective, knowledge-governance policies should use market-shaping devices in order to design policies to manage creative-destruction processes. These policies would seek to shape markets in order to reduce dynamic inefficiencies and increase dynamic efficiencies coming from Schumpeterian competition, a form of competition that, now, overuses intellectual property rules as one of its core weapons. From the perspective of firms, knowledge-governance policies should not be about preventing "market power" but about curbing its excesses: "unproductive entrepreneurship" and "rent extraction".

Within a knowledge-governance framework, the main policy concerns should be to mitigate structural inefficiencies and to increase access. Plant argued that patents can make the beneficiary "the owner of the entire supply of a product for 
which there may be no easily obtainable substitute", $(1934,30)$ a troubling claim. A clever, but not radical, innovation (for instance, market-niche dominance by Post $\mathrm{It}^{\circledR}$ notes from $3 \mathrm{M}$ ) should not raise major concerns among policy-makers dealing with competition issues. However, what are the implications of a proprietary general-purpose technology cornering the market? For instance, a new geneticengineering research tool or a particular DNA sequence)? Then Plant's point would hold completely, and the granting of a patent would create a substantial monopoly for the owner - and potentially prevent others from exploiting it - thus slowing the diffusion of a potentially radical innovation with obvious negative impacts on productivity growth.

In cases like those involving general-purpose technologies, IP rules and regulations should be much more rigorously examined and carefully constructed. A possible "tool" for dealing with them would be for the government to claim a golden share in the IPR system (especially patents and copyrights), by which it would be able to convert a property right previously granted into a general public license $^{16}$, as well as to profit from its dissemination ${ }^{17}$.

In sum, radical innovations - and, especially, general-purpose technologies - should be subjected to a special IPR regime in which the government's golden share should be able, if needed, to "shape" the market toward a more competitive institutional design (away from too secure - or broad - monopolies). ${ }^{18} \mathrm{~A}$ legitimate, and fair, reason to do so is that, as already mentioned above, according to some recent studies, the US government played a decisive part in the development of virtually all general-purpose technology, from interchangeable parts and mass production to DARPA and biotech (cf. RUTTAN 2006; WEISS 2007 and 2014; BLOCK 2008).

\footnotetext{
${ }^{16}$ That is, a legally enforced temporary monopoly.

${ }^{17}$ Meaning the ability to recover his costs, establish a robust competitive advantage and enjoy a sizable profit stream, but not the ability to exclude others from using and inventing around his innovation or protecting its diffusion. Taking as an example the Microsoft case, the battle should not be about "breaking" the company. The golden share would allow the government to force Microsoft to publish its source code. An open code would quickly get cleaned up and improved, consumers would benefit and new entrants would probably arise helping ignite the innovation race and dislodging Microsoft from its monopoly position while preserving the company's market power and ability to innovate.

${ }^{18}$ As a clever reader, you should, at this point, be asking "How can an innovation - or innovation cluster - be defined as radical before it 'matures' though a process that evidently takes time?" The answer is simple: it cannot. The proposal here is for public sources of funding and regulatory bodies, through the golden share or via special provisions similar to those behind the rationale for issuing compulsory licenses, to retain the option to classify an innovation cluster as a strategic general-purpose technology for potentially delivering "massive wealth creation." As such, those technologies would be treated similarly to weapons of mass destruction, but for inverse reasons. And that placement would happen ex-post, not ex-ante.
} 
Given both the complexity and diversity of knowledge-production regimes and R\&D funding, a one-size-fits-all prescription for knowledge appropriation (IPR rules) is not the best way to handle the matter. The 20-year length of a patent (or the terms of copyrights and registrations) is not a "scientifically established outcome" (LANDES and POSNER 2003). It is, rather, a convention - that is, a (lobby-based) institutional-legal construct that, as such, can very well be questioned and changed. ${ }^{19}$ Alternatively, consider this broad guideline for knowledge-governance policies: the length and breadth of patent protection, as well as innovations protected by copyrights, such as software, should be directly linked to the expenditures in R\&D, made by applicants in the development of a technology and inversely correlated with their market power. ${ }^{20}$ Thus, big research budgets (in terms relative to the firm's size) would, in principle, qualify better than "historical accidents" to earn legitimate protection. Conversely, "global players" would enjoy less legal protection than "garage outfits", given that the same legal contract would grant cumulative and increasing returns in the former case - reinforcing dominance - and, often, the ability to serve debt in the latter. Instead of one size fitting all, we would have something like - paraphrasing Rodrik - "many recipes under the same rule". ${ }^{21}$

As for the source of dynamic inefficiencies referred to above as strategic patenting, it should be dealt with in the same way David Ricardo suggested landlords should be addressed ${ }^{22}$ : earned but unused patents should be classified like fertile but uncultivated pieces of land in an environment structurally constrained by scarcity. They should be taxed, and progressively so. After an initial "launching period," each year of idleness in the commercialization of the patent should give rise to a severe

\footnotetext{
${ }^{19}$ As a matter of fact, a century ago, copyrights lasted for 14 years - and could be extended another 14 if the copyright holder petitioned for an extension. Today, corporate copyrights last for 95 years, and individuals retain copyrights for 70 years after their deaths. There was nothing "scientific" to back these changes but rather the powerful lobby of the entertainment industry. As for patents, the reader bear in mind that both in Switzerland (between 1850 and 1907) and in the Netherlands (between 1868 and 1912), industrialization occurred without enforcement of patent laws (cf. SCHIFF 1971).

${ }^{20} R \& D$ expenses as a percentage of the applicant's sales or assets could become a metric. That would require a close monitoring of R\&D evolution within firms. Assuming that those R\&D-intensive industries are also the ones bearing more fixed and sunk costs, plus near-future planned expenses tied to the "birth" of an innovation or technology, should be in the contract granting the rights and their actual production of the enabling mechanism to conclude the exam. Otherwise, patent pending would be a sort of "reasonable doubt" proviso.

${ }^{21} \mathrm{~A}$ very difficult emerging theme here is the protection to be given to traditional knowledge: DOC (Denominacione de Origine Controllata certifications that grant monopolies based on regional know-how and capabilities, like champagne versus sparkling wines) issues and related others. I acknowledge its importance but do not deal with that in this paper.

${ }^{22}$ The parallel here would be between the example given by David Ricardo of the unique fertility of a piece of privately owned land, which would generate increasing revenues to its owner, regardless of efforts to improve the land's productivity, and the stream of revenue generated from a patent regardless of whether its owner keeps innovating.
} 
fine, the exact amount of which should be left to specialists in the field but could very well be an increasing percentage of the patentee's sales or assets. Does this sound rigorous? Yes, it does, but patents and IPRs are legally conceded monopolies and matters of public interest. ${ }^{23}$ They are too important to be left to private law firms to design and to corporations to govern. ${ }^{24}$

Additionally, the kind of approach to the governance of knowledge I am pointing to should have as its core principle the discouragement of the sort of unproductive entrepreneurship that Baumol highlighted more than three decades: A type of legal entrepreneurship that turns law firms into very big and profitable corporations but with zero impact on the economy's real productivity. It would, in sum, help to trigger the "relocation of entrepreneurship" - from courts back to labs - as claimed by Baumol (1993 and 2002).

Another key point outlined in Section II above relates to the relationship between the "digitally renewed economy" and intellectual property issues, and particularly to the risk of winner-takes-all market outcomes (cf. VARIAN et al. 2004; CARLTON and GERTNER 2002). Knowledge-governance policies here should pursue, very aggressively if needed, public enforcement of standards development, cooperativestandards setting, the stimulation of (instead of restriction on) joint research ventures and other forms of research coordination and venture capital financing to multiple sources of experimentation (BLOCK and KELLER 2011). The aim should be a "less kind, less gentle patent system," as Jaffe and Lerner (2002) put it, in which patents are much harder to acquire and easier to share.

Also of concern is the recent wave of IPR expansion and its connection to a potential "information feudalism" or "second enclosure movement." This movement is analyzed by "progressive IP lawyers", software programmers and a sizable number of social and natural scientists of various extractions as a recipe for global monopoly, one that is likely to stifle innovation at the same time as it concentrates

\footnotetext{
${ }^{23}$ In that sense, they are very similar to the financial industry and especially to the banking sector.

${ }^{24}$ Google offers a striking example on that matter: it has just bid US\$900 million for the patent portfolio of Nortel Networks, the Canadian telecom-equipment maker, as part of a strategy to defend itself against patent litigation. The amount of money involved signals how fierce the patent wars have become, particularly in Silicon Valley, where even the largest and most powerful companies, like Google, are besieged by dozens of patent-infringement suits. It also underscores Google's frustration with the state of the patent-reform legislation in Congress.

Though Google could potentially use some of the technology in the Nortel patents in future research, the company said it wanted to buy them to defend itself against patent litigation. By building a large portfolio of patents, Google keeps them out of competitors' hands. It also hopes to dissuade other companies from suing it, either because Google holds similar patents to the ones they might sue over or as deterrence - if you sue me, I will sue you (NYT 5 April 2011).
} 
wealth (see Moglen 2003, Benkler 2003 and BurlamaquI and Cimoli: 2014). A number of commentators have called for an alternative to this second enclosure, an alternative they term "the new commons". ${ }^{25}$ As Evans $(2005,3)$ has aptly put it, this alternative is "attractive both because of its distributional implications and because of its potential for raising the rate of innovation and value creation". From a knowledge-governance perspective, the basis of the new commons comes from a redefinition of "ownership": from the focus on the right to exclude to the focus on the commitment to distribute (disseminate).

The key idea here is that once property rights are redefined along the lines pioneered by the open-source software movement, a much more egalitarian redistribution of intangible assets and a more powerful rationale to foster innovations will be able to emerge. This rationale is one that unfolds from the characteristics of the networked information economy - an economy of information, knowledge and culture that flows over a ubiquitous, decentralized network.

In that environment, as Benkler remarks, productivity and growth can be sustained in a pattern that differs fundamentally from the industrial economies of the twentieth century in two crucial characteristics. First, network based knowledge creation can play a much more important role than it could in the physical economy. Individuals and teams working cooperatively alongside firms can make a difference in the creation of innovative solutions and productivity gains (BENKLER 2003, 1 and 2006). ${ }^{26}$ Second, decentralized production and distribution networks, whether market-based or not, can similarly play a much more important role by increasing the diversity of ways of organizing production and consumption and, therefore, by increasing the sources and possibilities for multiple forms of experimentation.

This is clearly a global issue and - because of its global scope, and also because of the under-theorized relationship between innovation, competition policies and intellectual property rights - a very difficult one to handle. It will certainly require the active involvement of governments in encouraging and assisting the development of open-source systems to move society toward more general-publiclicenses-oriented IPR regimes. It will also require international cooperation - both very turbulent matters from a power-politics perspective. Nevertheless, the recent

\footnotetext{
${ }^{25} \mathrm{~A}$ "commons" is a piece of land over which people can exercise certain traditional rights in common, such as allowing their livestock to graze upon it. Older texts use the word "common" to denote any such right, but more modern usage is to refer to particular rights of common and to reserve the name "common" for the land over which the rights are exercised. By extension, the term "commons" has come to be applied to other resources that a community has rights or access to.

${ }^{26} \mathrm{And}$, he adds, one can clearly observe this behavior by noticing that most of what we do on the Internet runs on software produced by tens of thousands of volunteers, working together in a way that is fundamentally more closely related to a community than to a hierarchical big corporation standing alone.
} 
decisions by IBM and Nokia, for example, to put part of their patents into the public domain suggests that there is perhaps more room to maneuver than the skeptical analyst might expect.

\section{Conclusion}

The knowledge-governance-oriented policy-institutions framework I have proposed would be flexible and pragmatic and have creative-destruction management and maximum expansion of access to knowledge as its main goals. In its innovation- and competition-policies dimension, it would not be anti-bigness per se, but anti-unproductive entrepreneurship (BAUMOL 1993 and 2002); pro-efficiency but not libertarian (in the "Chicago School" sense of letting the market, almost always, take care of its own problems); and, especially, pro-cooperation, leaving room for business networks to thrive and for state-sponsored administrativeguidance initiatives. It would also engineer policies toward the development of multiple sources of experimentation and allow room for industrial and technology policies without jeopardizing its own core theoretical foundations.

In its intellectual-property dimension, it should not point to a one-size-fits-all institutional design and should not pursue the maximum protection of monopolistic rents, as both the US PTO and the WTO seem to be doing. It should search, instead, for the minimal common denominator, allowing for institutional and technological diversity and space for distinctive developmental strategies (BOYLE 2004, 2008; RODRIK 2011). It should take into account the asymmetries in the distance to the "development frontier" among countries and regions, echoing Joseph Stieglitz's wise remark that "Intellectual property is certainly important, but the appropriate IPR system for an emerging country is different than the IPR system best fitting already developed nations" (STIGLITZ 2005). ${ }^{27}$

From an evolutionary perspective, the key issue to deal with is how to separate innovation-rooted profits, which should be rewarded but understood as temporary (their continuity dependent on continuous innovation), from legal monopoly-granted rents, which should be eliminated or, at least, closely monitored and curtailed.

None of these policy prescriptions will be achieved without a huge dose of "strategic state action"; and most of them will require a high degree of state capacity as well as international treaties redesign (such as the GATS ${ }^{28}$ under the

\footnotetext{
${ }^{27}$ One of the main reasons for that, although certainly not the only one, is that the big pharmaceutical companies perform obscene price discrimination among nations (cf. VARIAN et al. 2004, 52) and almost always refuse to engage in poor and emerging countries' public policies oriented toward health care.

${ }^{28}$ General Agreement on Trade in Services.
} 
WTO). This is an uneasy task; nonetheless, the expected result, to which this paper intends to make a small contribution, would be a theory/policy framework linking, conceptually, innovation and Schumpeterian competition to competition policies and intellectual-property-rights management, which will allow room for a more open, democratic and development oriented knowledge ecology.

\section{Acknowledgment}

I would like to thank Fred Block, Yochai Benkler, Rainer Kattel and Richard Nelson for suggestions concerning both form and content for a previous version of this paper.

\section{References}

Anthony, S. 2000. "Antitrust and Intellectual Property Law: From Adversaries to Partners." AIPLA Quarterly Review 28(1). Available at http://www.econ.jhu.edu/ People/Hamilton/antitrust/ftcip.doc .

AUstin, I. 2009. Common Foundations of American and East Asian Modernization: From Alexander Hamilton to Junichero Koizumi. Singapore: Select Publishing.

BAUMOL, W. 1993. Entrepreneurship, Management and the Nature of Payoffs. Cambridge, MA: MIT Press.

BAUMOL, W. 2002. The Free-Market Innovation Machine. Princeton: Princeton University Press.

BenkleR, Y. 2003. "Freedom in the Commons: Towards a Political Economy of Information." Duke Law Journal 52, 1245-1276.

BENKLER, Y. 2006. The Wealth of Networks. New Haven: Yale University Press.

BEST, M. 2001. The New Competitive Advantage. Oxford: Oxford University Press.

BlaUg, M. 2005. "Why Did Schumpeter Neglect Intellectual Property Rights?" Review of Economic Research on Copyright Issues 2, 69-74.

BLoCK, F. 2008. "Where Do Innovations Come From? Transformations in the U.S National Innovation System - 1970-2006." Research paper for The Ford Foundation, Grant \#1075-1307.

BLOCK, F. and M. KelLeR. 2011. "Where Do Innovations Come From? Implications for Intellectual Property."

BOYLE, J. 2003. "The Second Enclosure Movement and the Construction of the Public Domain." Available at http://www.law.duke.edu/boylesite/ (last accessed 1 August 2011).

BOYLE, J. 2004. "Manifesto on the Future of WIPO." Available at http://www.law. duke.edu/boylesite/ (last accessed 1 August 2011).

BoYLE, J. 2008. The Public Domain. New Haven: Yale University Press. 
BRoWN-KeYDER, V. 2007. "Intellectual Property: Commodification and Its Discontents." In A. Bugra and K. Agartan (eds). Reading Karl Polanyi for the Twenty-First Century: Market Economy as a Political Project. New York: Palgrave Macmillan, 155-170.

BRYNJOLFSSON, E. and B. KAHIN (eds.). 2002. Understanding the Digital Economy. Cambridge, MA: MIT Press.

Burlamaqui, L. 2000. "Evolutionary Economics and the Role of State." In L. BURLAMAQUI, A. Castro and H. J. Chang (eds). Institutions and the Role of the State: New Horizons in Institutional and Evolutionary Economics. Cheltenham: E. Elgar,

BURlAMAQUI, L. 2009a. "Innovation, Competition Policies and Intellectual Property: An Evolutionary Perspective and its Policy Implications." In N. Netanel (ed.). The Development Agenda: Global Intellectual Property and Developing Countries. Oxford: Oxford University Press,

BurlamaquI, L. 2009b. "Notes on Knowledge Governance." The Ford Foundation (unpublished).

BurlamaquI, L. 2010. "Intellectual Property, Innovation and Development." Brazilian Journal of Political Economy 30(4).

BURlAMAQUI, L and Cimoli, M. 2014."Industrial Policy and IPR: A Knowledge Governance Approach" in Cimoli, Dosi, Maskus Okediji, Reichman and Stiglitz (Eds): Intellectual Property Rights - Legal and Economic Challenges for Development. Oxford University Press, pp: 477-502.

Burlamaqui, L. and A. ProençA. 2003. "Inovação, Recursos e Comprometimento: Em Direção a uma Teoria Estratégica da Firma." Revista Brasileira de Inovação 1(3), 4-35.

Cartton, D. and R. Gertner. 2002. "Intellectual Property, Antitrust and Strategic Behavior." NBER Working Paper 8976.

CHANG, H.-J. 2002. Kicking Away the Ladder. London: Anthem Press.

CIMOLI, M. and A. PrIMI. 2007. "Technology and Intellectual Property: A Taxonomy of Contemporary Markets for Knowledge and their Implications for Development." CEPAL. Unpublished Manuscript.

DE Long, B. 2000. The Dilemma of Antitrust: A Short History. Available at http:// econ161.berkeley.edu/ (last accessed 1 August 2011).

Dixon, P. and C. GREenLALGH. 2002: The Economics of Intellectual Property: A Review to Identify Themes for Future Research. Manchester: CRIC.

DRAHOS, P. and J. BRAITHWAITE. 2002. Information Feudalism. New York: The New Press. DreCHSLER, W. 2005. "The Rise and Demise of the New Public Management." Post-autistic Economics Review 33, 17-28. Available at http://www.paecon.net/ PAEReview/issue33/Drechsler33.htm (last accessed 1 August 2011).

Evans, P.B. 1995. Embedded Autonomy: States and Industrial Transformation. Princeton: Princeton University Press.

Evans, P.B. 2005. "The New Commons vs. the Second Enclosure Movement: Comments on an Emerging Agenda for Development Research." Studies in Comparative International Development 40(2), 85-94.

FLIGSTEIN, N. 2001. The Architecture of Markets: An Economic Sociology of TwentyFirst-Century Capitalist Societies. Princeton: Princeton University Press. 
FonG, G. 2001. "Arpa Does Windows: The Defense Underpinning of the PC Revolution." Business \& Politics 3(3), 213-237.

Georgescu-Roegen, N. 1935. "Note on a Proposition of Pareto." The Quarterly Journal of Economics 49, 706-714.

HARCOURT, B. 2011. The Illusion of Free Markets: Punishment and the Myth of Natural Order. Cambridge, MA: Harvard University Press.

JAFFE, A. and J. LERNER. 2002. Innovation and Its Discontents: How Our Broken Patent System Is Endangering Innovation and Progress, and What to Do About It. Princeton: Princeton University Press.

Jolly, A. and J. PHILPOTT (eds). 2004. A Handbook of Intellectual Property Management. London: Kogan Page.

KELSEY, J. 2007. Serving Whose Interests? The Political Economy of Trade in Services. London: Routledge.

LANDES, W. and R. POSNER. 2003. The Economic Structure of Intellectual Property Law. Cambridge, MA: Belknap Press.

LANGLOIS, R. 2001. "Technological Standards, Innovation and Essential Facilities: Towards a Schumpeterian Approach." In J. Ellig (ed.). Dynamic Competition and Public Policy: Technology, Innovation, and Antitrust Issues. Cambridge: Cambridge University Press,

MenelL, P. 1999. "Intellectual Property: General Theories." Working Paper. Berkeley: Center for Law and Technology.

Merger, R.P., P.S. MenelL and M.A. Lemley. 2003. Intellectual Property in the New Technological Age. New York: Aspen Publishers.

Mitchell, W. and R. Simmons. 1994. Beyond Politics: Markets, Welfare and the Failure of Bureaucracy. Boulder, CO: Westview Press.

Moglen, E. 2003. "Freeing the Mind: Free Software and the Death of Proprietary Culture." Fourth Annual Technology and Law Conference, University of Maine Law School, Portland, 29 June.

Nelson, R. 1996. The Sources of Economic Growth. Cambridge, MA: Harvard University Press.

NeLSON, R. 2007. "Building Effective Innovation Systems versus Dealing with Market Failures as Ways of Thinking About Technology Policy." Unpublished Draft.

NeLSON, R. et al. 2005. A Program of Study of the Processes Involved in Technological and Economic Catch Up. New York: The Earth Institute/Columbia University.

NolL, R. 2004. "The Conflict over Vertical Foreclosure in Competition Policy and in Intellectual Property Law. Stanford Institute for Economic Policy Research." Working Paper 03-22.

OdagiRI, H, Goto, A, SunAmi, A and Nelson, R (eds):2010. Intellectual Property Rights, Development and Catch-Up - An International Comparative Study. Oxford University Press.

PereirA, A. 2008. "Whither the Developmental State? Explaining Singapore's Continued Developmentalism." Third World Quarterly 29(6), 1189-1203. 
PlANT, A. 1934. Selected Economic Essays and Addresses. London: Institute of Economic Affairs.

PolANYI, K. 2001. The Great Transformation. New edition. New York: Beacon Press. ReInerT, E. 2007. How Rich Countries Got Rich ... and Why Poor Countries Stay Poor. London: Constable Books.

RoDRIK, D. 2011. The Globalization Paradox: Democracy and the Future of the World Economy. New York: Norton \& Company.

RUTTAN, V. 2006. Is War Necessary for Economic Growth? Oxford: Oxford University Press.

SCHERER, F. 1994. Competition Policies for an Integrated World Economy. Washington, DC: The Brookings Institution.

SCHERER, F. 1996. Industry Structure, Strategy and Public Policy. New York: Harper Collins.

SCHIFF, E. 1971. Industrialization without National Patents. Princeton: Princeton University Press.

SChUMPETER, J. 1994 [1942]. Capitalism, Socialism and Democracy. London: Routledge.

SCHUMPETER, J. 1997 [1934]. The Theory of Economic Development. New York: Transaction Publishers.

SHAPIRO, C. and H. VARIAN. 1999. Information Rules. Boston, MA: HBS Press.

StIGlitZ, J. 2005. "Erros e acertos da propriedade intelectual." O Globo, 29 August.

Technology Review. 2005 (June). Intellectual Property Issue. Cambridge, MA: MIT Press.

VARIAN, H., J. FARREL and C. SHAPIRO. 2004. The Economics of Information Technology. Cambridge: Cambridge University Press.

Vaughn, K. 1994. Austrian Economics in America: The Migration of a Tradition. Cambridge: Cambridge University Press.

WEBER, M. 1922 [1976]. Economy and Society. Berkeley: Berkeley University Press. WEISS, L. 2007. "Governing the Market for America." Research paper for The Ford Foundation, Grant \#1075-1307.

WEISS, L. 2008. "Crossing the Divide: From the Military-Industrial Complex to the Development-Procurement Complex." Paper presented at the Berkeley Workshop on "The U.S. as a Hidden Developmental State," UC Berkeley, 19-21 June.

WEISS, L. 2009. "The State in the Economy: Neoliberal or Neoactivist?" Paper presented at the workshop "Innovation Policies in Hard Times", Rio de Janeiro, September. 